\title{
India's outward foreign direct investments in steel industry in a Chinese comparative perspective
}

Citation for published version (APA):

Kumar, N., \& Chadha, A. (2008). India's outward foreign direct investments in steel industry in a Chinese comparative perspective. UNU-MERIT, Maastricht Economic and Social Research and Training Centre on Innovation and Technology. UNU-MERIT Working Papers No. 053

Document status and date:

Published: 01/01/2008

Document Version:

Publisher's PDF, also known as Version of record

\section{Please check the document version of this publication:}

- A submitted manuscript is the version of the article upon submission and before peer-review. There can be important differences between the submitted version and the official published version of record.

People interested in the research are advised to contact the author for the final version of the publication, or visit the DOI to the publisher's website.

- The final author version and the galley proof are versions of the publication after peer review.

- The final published version features the final layout of the paper including the volume, issue and page numbers.

Link to publication

\footnotetext{
General rights rights.

- You may freely distribute the URL identifying the publication in the public portal. please follow below link for the End User Agreement:

www.umlib.nl/taverne-license

Take down policy

If you believe that this document breaches copyright please contact us at:

repository@maastrichtuniversity.nl

providing details and we will investigate your claim.
}

Copyright and moral rights for the publications made accessible in the public portal are retained by the authors and/or other copyright owners and it is a condition of accessing publications that users recognise and abide by the legal requirements associated with these

- Users may download and print one copy of any publication from the public portal for the purpose of private study or research.

- You may not further distribute the material or use it for any profit-making activity or commercial gain

If the publication is distributed under the terms of Article $25 \mathrm{fa}$ of the Dutch Copyright Act, indicated by the "Taverne" license above, 


\title{
UNITED NATIONS \\ UNIVERSITY
}

\author{
UNU-MERIT
}

\section{Working Paper Series}

\section{\#2008-053}

\section{India's Outward Foreign Direct Investments in Steel Industry in a Chinese Comparative Perspective}

\author{
Nagesh Kumar and Alka Chadha
}




\title{
India's Outward Foreign Direct Investments in Steel Industry in a Chinese Comparative Perspective
}

\author{
Nagesh Kumar and Alka Chadha \\ Correspondence: Director-General, Research and Information Systems (RIS), Core IV B, \\ Lodhi Road, New Delhi 110003, Email: nkumar@ris.org.in \\ Correspondence: Department of South Asian Studies, National University of Singapore, \\ Email: alkachadha@gmail.com
}

\begin{abstract}
Indian and Chinese enterprises have emerged as important outward investors in recent times with their involvement in a number of prominent Greenfield investments and acquisitions. The theory of international business posits that the ownership of some unique advantages having a revenue generating potential abroad combined with the presence of internalization and locational advantages leads to outward FDI. Conventional MNEs based in the industrialized countries have grown on the strength of ownership advantages derived from innovatory activity that is largely concentrated in these countries. It examines the case of steel industry that has become an important sector of overseas activity for Chinese and Indian companies with a string of major acquisitions of foreign MNEs for acquiring footprints and natural resources in order to identify the sources of ownership advantages and strategies of outward investments from emerging countries.
\end{abstract}

JEL codes: O1, L61

Key words: FDI outflows, steel, India

\author{
UNU-MERIT Working Papers \\ ISSN 1871-9872
}

Maastricht Economic and social Research and training centre on Innovation and

Technology, UNU-MERIT

\begin{abstract}
UNU-MERIT Working Papers intend to disseminate preliminary results of research carried out at the Centre to stimulate discussion on the issues raised.
\end{abstract}




\section{Introduction}

An important trend of the past decade is the emergence of significant outflows of foreign direct investments originating in developing countries. In particular, outward foreign direct investments (OFDI) from emerging countries such as China and India besides Brazil and South Africa have grown in salience over the past few years and represent evolution of a new set of corporate players on the global stage based in these countries. These new players, or emerging multinational corporations (E-MNEs) are undertaking OFDI for acquiring global footprints, securing raw materials supplies, and access to technology and brands, among other strategic assets. It is of interest to examine the emerging trends, motivations, entry modes, and sources of strength or ownership advantages of the E-MNEs, in terms of the theory of internationalization of firms. For such an analysis, steel industry represents an important industry for a study for two reasons. Firstly, the epicenter of the steel industry has shifted to Asia led by fast growing production and consumption in China, India and other Asian countries. Secondly, steel industry has attracted some of the prominent acquisitions in recent times involving E-MNEs, for instance, acquisition of Corus and NatSteel by Tata Steel, among others. Furthermore, it will be interesting to compare the performance of Indian enterprises in a Chinese comparative perspective, as Chinese steel industry has grown rapidly to assume a dominating position in the world with a number of enterprises undertaking OFDI.

\section{Government Policy towards Outward FDI in India and China}

\section{Evolution of Indian Government Policy}

The early policy of the Indian government towards outward FDI in force during the 1970s permitted only minority participation by Indian companies by way of export of capital goods rather than cash outflows in view of domestic capital and foreign exchange scarcity. In April 1978, an Inter-Ministerial Committee in the Ministry of Commerce was set up to clear proposals for Overseas Investments. As a part of economic reforms since 1991, policy governing outward investments was also liberalized in 1992 when an automatic approval system for overseas investments was introduced, and cash remittances were allowed for the first time. The total value of investment was restricted to $\$ 2$ million with a cash component not exceeding $\$ 0.5$ million in a block of 3 years. In 1995 a single window was created in the Reserve Bank of India (RBI), a fast track route was introduced and investment limit was raised from \$ 2 million to \$ 4 million. Beyond USD 4 million, approvals were considered under Normal Route at the Special Committee level. Investment proposals in excess of US \$ 15.00 million were considered by MoF with the recommendations of the Special Committee and generally approved if the required resources were raised through the GDR route. With the introduction of Foreign Exchange Management Act in 2000, the policy with respect to outward investment was overhauled and the limit for investment was raised to US\$ 50 million. Companies were allowed to invest 100 per cent of the proceeds of their ADR/GDR issues for acquisitions of foreign companies and outward direct investments. The limit was raised in March 2002 to US\$ 100 million for automatic route. In a significant liberalization of policy governing outward investments in March 2003, government allowed Indian companies to invest under automatic route upto 100 per cent of their net worth. This limit was raised further to 200 per cent of net worth in 2005, to 300 per cent of net worth in 2007, and finally to 400 per cent of net worth in 2008 to facilitate large acquisitions as the foreign exchange reserves of India built up. ${ }^{i}$ The government policy, therefore seems to have been guided by the relative foreign exchange scarcity in the country besides the recognition of the importance of outward investments for the overall competitiveness of Indian industry. It has three distinct phases of evolution, viz. restrictive policy during 1978-92, permissive policy during 19922003, and liberal policy, since 2003 (Nayyar 2007). 
Recognition of the outward investments for competitiveness of enterprises has also resulted in creation of financing facility for outward investments by Indian companies through the Export-Import Bank of India (Exim Bank). Exim Bank has extended term loans to Indian companies for funding their investments in overseas affiliates ever since its inception in the early 1980s. Currently the Bank's Overseas Investment Finance (OIF) program provides financing for both equity as well as loans of Indian companies in their affiliates abroad. Since April 2003, Indian commercial banks have also been permitted to extend credit to Indian companies for outward investments. In November 2006, the prudential limit on the bank financing was raised from 10 per cent to 20 per cent of overseas investment. From 2005, Indian firms were allowed to float special purpose vehicles in international capital markets to finance acquisitions abroad facilitating the use of leveraged buy-outs in international financial markets. Therefore, they were provided access to the expanding international capital market. India has also concluded bilateral investment promotion agreements with 63 countries and double taxation avoidance agreements with a similar number of countries. While the enabling policy and access to international markets facilitated outward investments by Indian enterprises, these cannot be adequate by themselves. As per the theory of international operations of firm, a firm needs ownership of certain unique assets to be successful abroad.

\section{Chinese Government's Policy towards Outward FDI}

The development of China's outward FDI is a reflection of the country's changing ideology and policies toward MNEs and internationalization. The eighties saw a strong opposition and debates regarding overseas investment and its incompatibility with socialism. It was in 1985 that the first concrete step was taken for promoting overseas investments by the Ministry of Foreign Economic Relations and Trade (MOFERT) when the government released the regulations regarding FDI outflows in its Provisions Governing Control and Approval Procedures for Opening Non-Trade Enterprises Overseas. It clearly stipulated that all economic entities and not just trading companies would be eligible for overseas ventures. Internationalization of Chinese large state-owned enterprises was also promoted in China's coastal regions so as to take advantage of international resources and international division of labor. China's coastal-oriented export-led development strategy opened up 14 coastal cities in 1988 and 4 special economic zones. Chinese large state-owned enterprises were for the first time authorized to invest overseas and this was linked with the government's political and economic agenda of expanding China's trade. However, the Asian financial crisis of 1997 led to stricter requirements for approval of overseas investments, which resulted in a slowdown of FDI outflows in the late nineties.

The turnaround came with China's accession to the WTO in 2001 when Premier Zhu Rongji announced the "going abroad" strategy in the $10^{\text {th }}$ five-year plan (2001-2005) and increasing outward FDI became the declared policy of China in order to utilize the growing trade surplus and reduce pressure on the domestic economy. The government now actively promotes outward FDI as an integral part of China's economic development strategy and as a response to competition and globalization. In fact, approval for outward investment clearly requires that the FDI outflow should be technology-acquiring, resource-seeking, marketseeking and foreign exchange-generating (Cheng and Stough, 2007).

China's Export-Import Bank has also done its bit to boost FDI outflows by providing loans to firms for outward investments for resource development and infrastructure. Moreover, in case the investment is undertaken in a low-income country, then Chinese firms qualify for 
preferential loans. Fiscal incentives are also provided to firms that use Chinese machinery, plant, and equipment in their overseas ventures. China has also signed bilateral investment treaties with 103 countries and double taxation treaties with 68 countries to support the international expansion of Chinese enterprises.

To sum up, the government policy of the two countries has evolved from a restrictive attitude to more liberal and even promotional policy towards OFDI based on recognition of their role in the country's external competitiveness and with accumulation of foreign exchange reserves. It is only in this decade that the Indian and Chinese companies could undertake large acquisitions and Greenfield investments abroad.

\section{Outward FDI from India in a Chinese Comparative Perspective Growing Significance of Emerging Countries}

Table 1 shows that outward investments from developing countries have over time gained in salience accounting for 14 per cent of global outflows in 2006 compared to just 8 per cent in 2003. The importance of key emerging economies namely Brazil, China, South Africa and India as sources of outward FDI among developing countries has increased over the past few years, as highlighted in the literature (Wells 1983, Lall 1983, Kumar 1998, Aykut and Ratha 2004, UNCTAD 2005, 2006; Goldstein 2007; among others). Their importance as sources of FDI has gone up in recent years with their combined share going up from 12 per cent in 2003 to 16 per cent in the next two years to a staggering 35 per cent in 2006 . It would appear that 2006 has seen sharp rise in outward investments not only from India but also from Brazil, South Africa and China as well. It remains to be seen whether the increased was resulting due to some large acquisitions or whether it is the new scale of activity that will be sustained in the coming years. Some of outward investments are reported as emerging from tax havens such as British Virgin Islands and Cayman Islands and could be attributed to round tripping.

In terms of absolute magnitudes, share of outward FDI from India in outflows from developing countries at 6 per cent compared to 9 per cent for China is impressive considering the fact that Chinese economy is nearly 2.5 times that of India. Another comparison across countries is in terms of outward FDI as a percentage of gross fixed capital formation (GFCF) in the source economy also reported in Table 1. It suggests that the share of O-FDI in GFCF was higher for India than China in 2003-2004, roughly comparable in 2005 and again in 2006. 
Table 1: FDI Outflows from Emerging Countries

\begin{tabular}{|c|c|c|c|c|}
\hline & 2003 & 2004 & 2005 & 2006 \\
\hline World & 560087 & 877301 & 837194 & 1215789 \\
\hline Developed economies & 503966 & 745970 & 706713 & 1022711 \\
\hline $\begin{array}{l}\text { Developing economies } \\
\% \text { share in total }\end{array}$ & $\begin{array}{c}45372 \\
(8) \\
\end{array}$ & $\begin{array}{c}117336 \\
(13) \\
\end{array}$ & $\begin{array}{c}115860 \\
(14) \\
\end{array}$ & $\begin{array}{c}174389 \\
(14) \\
\end{array}$ \\
\hline $\begin{array}{l}\text { China } \\
\% \text { share in developing countries }\end{array}$ & $\begin{array}{c}2855 \\
(6)\end{array}$ & $\begin{array}{c}5498 \\
(5)\end{array}$ & $\begin{array}{c}12261 \\
(11)\end{array}$ & $\begin{array}{c}16130 \\
(9)\end{array}$ \\
\hline $\begin{array}{l}\text { India } \\
\% \text { share in developing countries }\end{array}$ & $\begin{array}{c}1879 \\
(4)\end{array}$ & $\begin{array}{c}2179 \\
(2)\end{array}$ & $\begin{array}{c}2495 \\
(2)\end{array}$ & $\begin{array}{c}9676 \\
(6)\end{array}$ \\
\hline $\begin{array}{l}\text { Total share of } 4 \text { emerging countries } \\
\text { (viz. Brazil, India, China and South } \\
\text { Africa) }\end{array}$ & $(12)$ & $(16)$ & $(16)$ & $(35)$ \\
\hline \multicolumn{5}{|c|}{ FDI Outflows as a percentage of Gross Fixed Capital Formation } \\
\hline World & 8.4 & 10.1 & 9.2 & 11.8 \\
\hline Developed Countries & 10.3 & 11.8 & 11.1 & 14.1 \\
\hline Developing Countries & 2.1 & 5.5 & 4.7 & 6.4 \\
\hline China & 0.4 & 0.7 & 1.5 & 1.9 \\
\hline India & 0.8 & 1.2 & 1.4 & 5 \\
\hline
\end{tabular}

Source: Compiled from on-line UNCTAD's FDI database and UNCTAD World Investment Reports, 2004 and 2007.

\section{What Can be learnt from Sectoral Distribution of OFDI?}

Table 2 summarizes the sectoral distribution of OFDI stocks of the two countries to get an idea of their focus. The sectoral breakup for Indian OFDI stocks is available for 2004 only which suggests that manufacturing accounted for nearly half of total OFDI stock of India. Services also had a substantial (40 per cent) share of OFDI stock with information and communication (ICT) services sector being the most important. The extractive sector was virtually non-existent upto 2000 . However, by 2004 its share had gone up to 11.4 per cent. In China's case, services comprising largely trading and business services besides finance accounted for 71 per cent share in 2006. Extractive sector also had a considerable proportion with a 21 per cent share. Manufacturing had a rather small share of 8.31 per cent in 2006. While the importance of services and manufacturing was declining, that of extractive sector was rising. It would appear from a comparison of sectoral composition of OFDI in the two countries that Indian enterprises were undertaking OFDI in manufacturing and services to pursue a strategy of horizontal expansion or internationalization of operations seeking global footprints, locating manufacturing bases across the borders. The OFDI of Chinese enterprises on the other hand seem to be motivated by vertical integration seeking access to natural resources and raw materials and trading of finished goods produced in China. The proportion of horizontal manufacturing bases is rather small. 
Table 2: Sectoral Distribution of OFDI Stocks of India and China

\begin{tabular}{|c|c|c|c|c|c|c|}
\cline { 2 - 7 } \multicolumn{1}{c|}{} & \multicolumn{3}{c|}{ India } & \multicolumn{3}{c|}{ China } \\
\hline & 2000 & 2004 & 2006 & 2000 & 2004 & 2006 \\
\hline Extractive & 65.18 & 1044.60 & n.a. & n.a. & 6785.60 & 18718.32 \\
\hline \% share in total & 1.47 & 11.44 & & & 15.15 & 20.65 \\
\hline Manufacturing & 1776.38 & 4423.98 & n.a. & n.a. & 4538.07 & 7529.62 \\
\hline \% share in total & 40.04 & 48.44 & & & 10.13 & 8.31 \\
\hline Services & 2595.37 & 3663.61 & n.a. & n.a. & 33453.59 & 64382.97 \\
\hline \% share in total & 58.49 & 40.12 & & & 74.71 & 71.04 \\
\hline Total & 4437.00 & 9132.00 & 12964.00 & 27768.00 & 44777.26 & 90630.91 \\
\hline
\end{tabular}

Source: Authors based on data collected from Indian and Chinese Government sources and UNCTAD.

\section{What can be learnt from comparisons of Indian and Chinese Enterprises?}

The above comparisons do not reflect on the profile of international enterprises originating in India and other emerging countries. A recent study by the Boston Consulting Group (BCG, 2008) has identified 100 companies (Global Challengers) from rapidly developing economies (RDEs) that are globalizing and are likely to emerge as global players. This list covers Indian companies along with those from 13 other emerging countries and hence could also be useful in putting the globalization of Indian enterprises in a comparative global perspective. The BCG list is dominated by two Asian countries namely China and India with 41 and 20 companies in global 100 respectively. The next country in the list viz. Brazil has only 13 companies. According to the key characteristics of Chinese and Indian companies summarized in Table 3, on average Indian companies are much smaller in scale compared to their Chinese counterparts but have much higher proportion of international sales at 47 per cent compared to just 17 per cent in case of Chinese companies. A striking difference is the fact that all the 20 Indian companies are publicly traded companies and none of them is state owned while 29 of 41 Chinese companies are state owned. A greater proportion of acquisitions (78\%) by Indian companies was in developed countries compared to those by Chinese companies (68\%). Therefore, profile of an Indian company emerges to be one of a fast growing and rapidly internationalizing company that is publicly traded and privately managed compared to larger state owned enterprises of China.

Table 3: Key Characteristics of Indian and Chinese Globalizing Companies

\begin{tabular}{|l|c|c|}
\hline & India & China \\
\hline No. of companies in BCG 100 & 20 & 41 \\
\hline Average size, US\$ billion & 3.9 & 14.5 \\
\hline CAGR, \% & 31 & 26 \\
\hline Share of international sales, \% & 47 & 17 \\
\hline Operating profit margin, \% & 16 & 14 \\
\hline CAGR of total share holders return, \% & 38.2 & 27.7 \\
\hline Public traded (quoted) & 20 out of 20 & 34 out of 41 \\
\hline State owned & None & 29 out of 41 \\
\hline M\&A deals by sample companies & 26 & 17 \\
\hline $\begin{array}{l}\text { Proportion of matured markets in M\&A } \\
\text { deals }\end{array}$ & 68 & 78 \\
\hline
\end{tabular}

Source: Compiled from BCG (2008). 
Another study suggests that the bulk of the Chinese outward FDI is concentrated in Hong Kong (64 per cent), Cayman Islands (15.6 per cent) and Virgin Islands (3.5 per cent) which may be driven by the round tripping considerations to take advantage of tax preferences for foreign investors prevailing in China. In terms of motivations, Chinese outward investments are dominated by outward investments made by three state owned oil companies viz. CNPC, CNOOC and SINOPEC which are driven by natural resource seeking motive, although some manufacturing companies such as Lenovo, TCL, Nanjing Auto are beginning to make acquisitions for technology and brands (Hagiwara 2006). The natural resource seeking investments are outward investments but not internationalization of operations. In India's case, most of the outward investments are undertaken generally by private enterprises seeking to internationalize their operations through horizontal acquisitions and Greenfield investments.

\section{Explaining FDI Flows from Developing Countries: What can be learnt from theory}

The theory of international operation of the firm - which has evolved over the years with the contributions from Hymer (1976), Caves (1971) and Dunning (1979) among many others posits that the ownership of some unique advantages having a revenue generating potential abroad combined with the presence of internalization and locational advantages leads to OFDI. Enterprises based in the industrialized countries have emerged as MNEs on the strength of ownership advantages derived from innovatory activity that is largely concentrated in these countries. Very little is known about the sources of the strength of enterprises based in developing countries, such as India, that enables overseas investment.

Kumar $(2007,2008)$ has argued that the main source of the advantage enjoyed by Indian enterprises was their ability to develop cost effective processes and products. This frugal engineering capability has resulted from Indian enterprises' evolution in a low country setting and hence dealing with highly price conscious and demanding customers. As the volumes in India lay at the bottom of the pyramid, the companies focused on innovations for developing affordable yet functionally efficient products. Indian pharmaceutical and chemical enterprises developed cost-effective processes of known chemical entities and have emerged as the most competitive suppliers of generic medicines globally. Similarly, Indian automobile producers, in order to cater to some of the most demanding customers in the world at their home base has given to Indian companies a unique ability to deliver value for money epitomized in the development of world's cheapest car Nano, besides other innovations. Another source of their ownership advantage lay in their accumulated learning, organizational and managerial know how that enables them to manage operations across different cultural environments. Long production experience in India gives to Indian companies not only skills and organizational capability to manage large operations but also experience of managing in multicultural settings, given the cultural diversity of the country. This managerial capability also gives them the confidence of managing the acquired facilities besides Greenfield projects. Therefore, managerial capability has emerged as an important ownership advantage for Indian companies. Finally, their ability to raise finance especially for funding large acquisitions had also some thing to do with their evolution in India. Having operated under a system of prudential financial regulations and corporate governance, Indian companies generally enjoy healthy balance sheets and robust credit ratings. Most of them have been listed at Indian stock exchanges for decades and are actively quoted. A number of them have also listed themselves at the NYSE and have followed GAAP systems of accounting and corporate governance. Their healthy balance sheets and their proven organizational skills 
have enabled them to attract attention of international banks and financial institutions for funding their leveraged buyout programmes.

It has been argued that OFDI from India has evolved with three distinct phases (Kumar 2008). In the first phase until 1990, largely Indian companies operated small operations as joint ventures in poorer countries in Asia and Africa seeking markets based on adapted and scaled down technologies in relatively low technology sectors. The entry mode was Greenfield. With the onset of reforms with greater freedom to invest abroad, Indian companies made outward investments in other countries to support their exports with local presence. Hence, they began to be concentrated in developed and developing countries where the markets for Indian products and services existed. These investments were concentrated in select industries such as pharmaceuticals and IT software in which Indian companies developed some cost effective processes. The entry mode was largely Greenfield. This comprised the Second Phase in the evolution of Indian enterprises. The third phase in the evolution of Indian enterprises is driven by the motivation of Indian companies to acquire scale and global footprints. Hence it is largely directed at acquiring strategic assets such as brand names (as in the case of Tata-Tetley or White \& Mackay), established marketing networks (as in pharmaceutical industry), or access to customers (as in the case of Novelis or Corus in the western world), or access to clients (in IT industry), or technology (as in the case of wind turbines and gearbox technology by Suzlon, or for heavy range of trucks as in TataDaewoo), etc. The scales and magnitudes involved are large and the entry mode is often acquisition. These acquisitions are producing new set of global leaders e.g. Tata Steel becoming the fifth largest steel producer in the world after acquiring Millenium Steel, NatSteel and Corus.

The ownership advantages required for different motivations of OFDI will be different. For instance, a horizontal FDI establishing manufacturing base would require ownership assets in the form access to technology, capital, managerial know how and organizational capacity. For natural resource seeking investment will require skills and expertise in mining and exploration and capital. In the case of Chinese enterprises, their large scales of operation and accumulated expertise is a source of ownership advantage. Their government ownership gives them access to capital and other resources. The locational advantages will determine where the investment will be made. In the case of strategic assets seeking investments or market seeking investments, the bulk of the investments may be made in developed countries having firms with strategic assets and markets. The natural resource seeking investments will be made in natural resource rich countries such as Australia, Canada, African countries among others.

\section{Indian and Chinese Outward Investments in the Steel Industry} Emerging Patterns in Global Steel Industry

Traditionally, iron and steel have been considered as the commanding heights of the economy since their consumption is an important indicator of the stage of development of an economy. The development experience of countries regarding the relationship between GDP and steel consumption shows an inverted U-shape. The steel intensity of GDP increases with per capita income in the initial phases of development owing to the building of infrastructure like railways, roads and bridges, water and gas works, electricity generation and distribution, plant and machinery and ports and buildings. As the country advances economically, the industrial product mix changes and there is an added demand for steel due to the consumption of automobiles and other consumer durable goods. However, beyond a certain threshold level of income, further increases in GDP do not translate into higher demand for steel due to 
saturation of infrastructure and a greater weight of the services sector in the economy. In view of this the epicenter of the steel industry has been gradually shifting away from the EU and North America towards Asia led by strong demand and production in China and India (as shown in Figure 1).

Figure 1: Global Production of Finished Steel

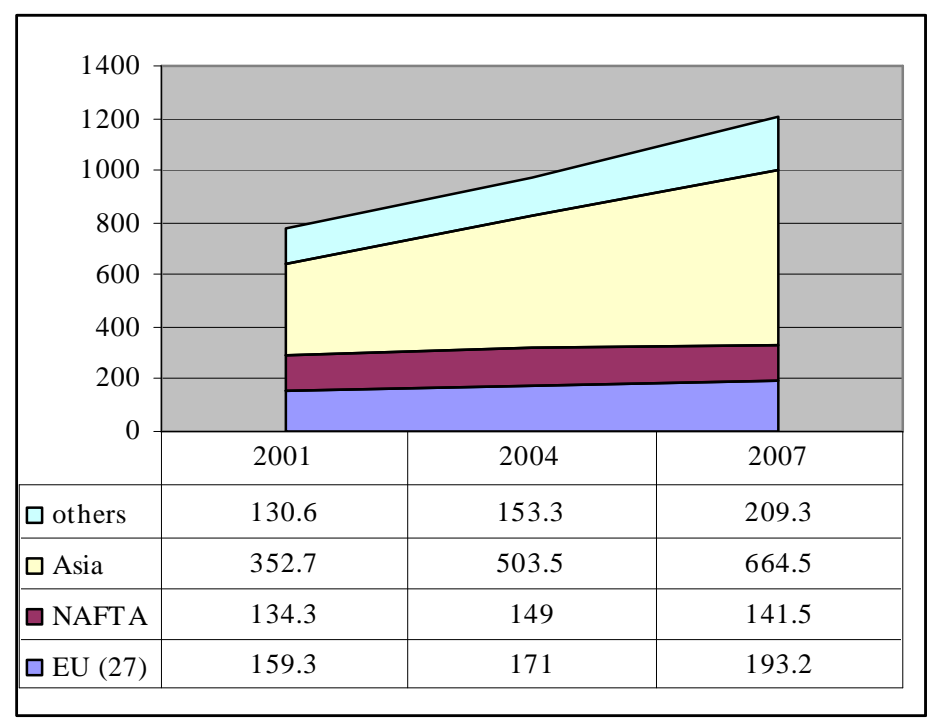

(million metric tones)

Source: based on International Iron \& Steel Institute (2008), World Steel in figures 2008, Brussels

Steel production is based on process know how and requires relatively large investments. Although the basic technology of steel making is matured and may be available on-the-shelf, some application technologies such as for special steels and alloys for special applications are more closely held. The other characteristic of the steel industry is its scale intensity. The third characteristic is its highly raw material dependent nature. Steel production requires abundant access to iron ore, coal, and energy. These factors namely increasing consumption in the emerging markets, technological maturity, scale economies and raw material intensity are leading to some consolidation of the industry. Arcelor-Mittal merger followed by Tata SteelCorus mergers are part of the trend of consolidation of the industry. Steel companies are acquiring upstream companies to utilize their cheap sources of raw materials or downstream producers to get access to consumers across borders. The steel industry has seen record mergers in the recent past including a number of mega-deals worth over $\$ 1$ billion. According to Bloomberg, steel companies were involved in $270 \mathrm{M} \&$ As worth $\$ 33$ billion in 2005 which rose to 347 M\&As valued at $\$ 95$ billion in 2006. According to an OECD (2007) study, the mining and processing of raw materials saw the biggest amount of cross-border M\&As in the OECD in 2006, followed by the telecommunication, financial and the media and entertainment sectors. In 2006, China and India ranked among the top 10 steel-producing countries of the world (see Table 5), with China being the largest producer accounting for 34 per cent of the world's output. 
Table 5: Major Steel-producing Countries, 2007 (Million Metric Tonnes)

\begin{tabular}{|l|c|c|c|c|}
\hline Country & \multicolumn{2}{|c|}{$\mathbf{2 0 0 7}$} & \multicolumn{2}{c|}{$\mathbf{2 0 0 6}$} \\
\hline China & 1 & 489.2 & 1 & 423.0 \\
\hline Japan & 2 & 120.2 & 2 & 116.2 \\
\hline United States & 3 & 98.2 & 3 & 98.6 \\
\hline Russia & 4 & 72.4 & 4 & 70.8 \\
\hline India & 5 & 53.1 & 5 & 49.5 \\
\hline South Korea & 6 & 51.5 & 6 & 48.5 \\
\hline Germany & 7 & 48.6 & 7 & 47.2 \\
\hline Ukraine & 8 & 42.8 & 8 & 40.9 \\
\hline Brazil & 9 & 33.8 & 10 & 30.9 \\
\hline Italy & 10 & 31.5 & 9 & 31.6 \\
\hline Turkey & 11 & 25.8 & 11 & 23.3 \\
\hline Taiwan, China & 12 & 20.9 & 12 & 20.1 \\
\hline France & 13 & 19.2 & 13 & 19.9 \\
\hline Spain & 14 & 19.0 & 14 & 18.4 \\
\hline Mexico & 15 & 17.6 & 15 & 16.4 \\
\hline Canada & 16 & 15.6 & 16 & 15.5 \\
\hline United Kingdom & 17 & 14.3 & 17 & 13.9 \\
\hline Belgium & 18 & 10.7 & 18 & 11.6 \\
\hline Poland & 19 & 10.6 & 19 & 10.0 \\
\hline Iran & 20 & 10.1 & 20 & 9.8 \\
\hline World & & $\mathbf{1 3 4 4}$ & & $\mathbf{1 2 5 1}$ \\
\hline Source: & & & \\
\hline
\end{tabular}

Source: International Iron \& Steel Institute (2008), World Steel in figures 2008, Brussels

The rise of China and India has led to significant changes in the global steel industry in the past two decades. India is still in the stage of low steel intensity and its per capita steel consumption is very low compared to international standards. China is rapidly catching up with the western levels of per capita consumption of steel (Table 6). A recent study by Tata Services (2006), the demand elasticity of steel with respect to GDP was found to be 0.95 from 1990-91 to 2005-06. Table 7 shows that the GDP elasticity of steel is higher for China at 1.15. It is not surprising since China accounts for more than one-third of the world steel consumption. India's steel consumption is much lower, merely one-tenth of China's. Though, Japan and USA have higher steel consumption, their elasticities are much lower. However, looking at the annual growth rates, we find that India comes next only to China. The demand for steel in India is going to rise in the coming decades rapidly as the country catches up with industrialization and development. Therefore, major steel groups from across the world have announced major programmes of investment in expanding production capacity e.g. POSCO, Arcelor Mittal, Tata Steel, Vedanta Resources, among others. Since 2001, world steel prices have tripled with rise in profitability and the steel intensity has increased in the recent past mainly owing to growing demand in Asia (Marsh, 2007). 
Table 6: Apparent Per Capita Steel Consumption

(kilograms finished steel products)

\begin{tabular}{|l|l|l|l|l|l|l|l|}
\hline & $\mathbf{2 0 0 1}$ & $\mathbf{2 0 0 2}$ & $\mathbf{2 0 0 3}$ & $\mathbf{2 0 0 4}$ & $\mathbf{2 0 0 5}$ & $\mathbf{2 0 0 6}$ & $\mathbf{2 0 0 7}$ \\
\hline $\begin{array}{l}\text { European } \\
\text { Union (27) }\end{array}$ & 329.4 & 327.0 & 328.6 & 349.9 & 335.0 & 378.9 & 392.0 \\
\hline NAFTA & 319.9 & 324.3 & 306.8 & 344.7 & 320.4 & 353.1 & 317.8 \\
\hline $\begin{array}{l}\text { Central and } \\
\text { South America }\end{array}$ & 90.3 & 83.9 & 85.9 & 98.0 & 94.4 & 105.6 & 119.0 \\
\hline Africa & 29.1 & 31.2 & 29.2 & 29.3 & 32.0 & 34.5 & 35.8 \\
\hline China & 123.5 & 148.5 & 185.4 & 211.4 & 252.7 & 273.6 & 307.3 \\
\hline India & 26.8 & 28.4 & 30.1 & 31.6 & 35.2 & 39.6 & 43.4 \\
\hline Japan & 575.2 & 562.4 & 575.2 & 601.1 & 609.6 & 617.4 & 625.9 \\
\hline South Korea & 814.0 & 924.3 & 956.0 & 990.3 & 984.4 & $1,044.2$ & $1,135.5$ \\
\hline Asia & 104.2 & 116.6 & 130.9 & 143.7 & 159.4 & 167.9 & 183.5 \\
\hline $\begin{array}{l}\text { Australia and } \\
\text { New Zealand }\end{array}$ & 268.2 & 298.1 & 308.3 & 327.0 & 321.2 & 315.8 & 340.7 \\
\hline
\end{tabular}

Source: International Iron \& Steel Institute (2008) World Steel in figures 2008

Table 7: Country-wise Steel Consumption, Industry Share and Elasticity of Steel

\begin{tabular}{|l|c|c|c|c|}
\hline & $\begin{array}{c}2005 \\
\text { Share of world steel } \\
\text { consumption (\%) }\end{array}$ & $\begin{array}{c}1995-2005 \\
\text { CAGR } \\
(\%)\end{array}$ & $\begin{array}{c}2004 \\
\text { Share of industry } \\
\text { in GDP }(\%)\end{array}$ & $\begin{array}{c}\text { GDP elasticity } \\
\text { of steel }\end{array}$ \\
\hline Brazil & 1.7 & 3.4 & 40 & 1.88 \\
\hline China & 31.1 & 13.7 & 46 & 1.15 \\
\hline India & 3.1 & 5.3 & 27 & 0.95 \\
\hline Japan & 7.7 & -0.2 & 31 & -0.67 \\
\hline USA & 10.2 & 0.3 & 22 & 0.23 \\
\hline
\end{tabular}

Source: Tata Services (2006)

\section{Indian Steel Industry}

The economic reforms of 1991 freed the steel industry from the shackles of government control by delicensing private investment in steel and abolishing administered prices. The new steel policy not only dereserved the integrated steel plant from the public sector but in a turn-around from past policies, started the privatization of public sector steel companies by divesting their shares in the stock market. The liberalization process set in motion by the reforms also did away with restrictions on private domestic and foreign investments. FDI was allowed into this sector with foreign equity participation up to 51 percent subject to the restrictions that foreign equity has to cover not only the cost of imports of capital goods but also foreign technology agreements till a specified limit. All these policy changes opened up new opportunities for growth for Indian steel enterprises and new plants were set up with latest technology and large production capacities such as Essar Gujarat and Jindal Strips.

As far as the market structure of the Indian steel industry is concerned, the market for finished steel has three large players - the Steel Authority of India (SAIL), Rashtriya Ispat Nigam Limited (RINL) and Tata Steel - which account for about half the supply of steel (Sengupta, 2004). These three enterprises do not compete with each other directly due to differentiations arising from product mix and location. Even though the freight equalization 
scheme has been dismantled to a large extent, these differentiations would enable them to enjoy monopolistic privileges in separate markets for specified products. These are large enough to influence market prices where as the large number of small and medium producers supply steel at market-determined prices. The pricing decisions of these large steel enterprises are in turn determined by import prices and the open market price movements. Thus, the international environment has a significant impact on the functioning of the domestic market in an integrated open economy and outward-orientation strategies become imperative for enhancing competitiveness.

India's comparative advantage lies in its availability of good quality iron ore at only $\$ 10$ per tonne for plants with captive mines and $\$ 20$ per tonne for iron ore purchased from the market which is much cheaper than the cost of \$30-40 per tonne prevailing in developed countries. Earlier, captive mines used to reduce productivity and quality but now these same captive mines have become a source of advantage because of their lower cost in the face of changing global demand ${ }^{1}$. Even the cost of labour is much lower in India in the range of \$1-1.5 per labour hour as opposed to $\$ 30-40$ per labour hour in the developed countries. On the flip side, the energy costs of steel making in India are relatively high, being 33 percent of total costs compared to 20 percent in developed countries. Similarly, the productivity of Indian labour is also low ranging between 80-190 tonnes per man year against a high of 300-500 tonnes per man year for developed countries (Sengupta, 2004). This is owing to the lack of technical upgradation of steel plants, outdated production processes, overmanning and low skill development. To overcome these shortfalls, the Indian steel industry is in the process of technological and organizational restructuring in order to compete effectively with foreign firms. There are variations across the enterprises in terms of competitiveness. Tata Steel had emerged one of the most competitive steel producers in the world even before it acquired Corus and other enterprises in East Asia.

\section{Emerging Patterns of Outward FDI from India and China in Steel Industry}

Given the scale economies in the steel industry, it is dominated by a few large enterprises in different countries. In India, Steel Authority of India (a public sector company), Tata Steel, Essar Steels, JSW Steels and Ispat Industries are prominent players in the industry. Similarly in China, Sinosteel, Baosteel, Capital Steel, are the key enterprises in the steel industry. In order to examine the OFDI activity of steel enterprises in the two countries, we gathered information on OFDI activity of two major enterprises from each country. These are Tata Steel and Essar Steel in India (both private sector players), and Sinosteel and Baosteel in China. The emerging patterns in OFDI activity of these companies is summarized in Tables 8 and 9 respectively.

Table 8 suggests that of the 6 major overseas investments made by Tata Steel, two are Greenfield market-seeking investments developing production facilities in Vietnam and South Africa respectively. One is natural resource-seeking investment of minority nature in Australian coal mining project. The key outward investments are acquisitions of NatSteel in Singapore, Millennium Steel in Thailand, and Corus in UK. Of these NatSteel and Corus were motivated by the urge to achieve scales and global footprints. NatSteel operates in 9 Southeast and East Asian countries. Corus has global operations and is the second largest steel company in Europe. Through these acquisitions, Tata Steel now has footprints in about 40 countries across the globe and has emerged as the sixth largest steel producer in the world. Tata-NatSteel-Millenium-Corus acquisitions bring together Tata Steel's low cost production

\footnotetext{
${ }^{1} \mathrm{We}$ are grateful to an anonymous referee for suggesting this explanation.
} 
bases and their access to natural resource endowments in India, with the access to processing technology and consumers. There are some indications that such a restructuring and production networking is taking place. Apparently Tata Steel and NatSteel plants in different Southeast Asian countries are being covered by a scheme of regional production network involving pallets going from India to the NatSteel plants and special steels to come from NatSteel's Southeast Asia plants to India. This way the synergy or the locational advantages of India emanating from the iron ore deposits will be available to the NatSteel plants and their specialization for some special steels to Tata Steel, will be exploited for mutual advantage. Essar Steel's acquisitions of Algoma Steel in Canada was also driven by a similar motivation of acquiring global footprints. Essar is building two Greenfield plants in Vietnam and Trinidad and Tobago respectively as a part of horizontal market seeking strategy. It has also undertaken acquisition of a mining company in the US as a part of natural resource seeking strategy.

It would appear therefore, that Indian steel companies' overseas activity is motivated by essentially internationalization of operations or acquisition of global footprints objective.

Table 8: Outward Investments made by Leading Indian Steel Companies

\begin{tabular}{|c|c|c|c|c|c|c|}
\hline Name & Country & $\begin{array}{c}\text { Value } \\
\text { (US \$ } \\
\text { million)/ }\end{array}$ & $\begin{array}{c}\text { capacity } \\
\text { (million } \\
\text { m.t.) }\end{array}$ & Year & Motivation & Entry mode \\
\hline \multicolumn{7}{|c|}{ Tata Steel's Overseas Subsidiaries/ Affiliates } \\
\hline Corus Steel PLC & $\begin{array}{l}\text { Plants in U.K./ } \\
\text { Netherlands and } \\
\text { global presence }\end{array}$ & 12100.00 & 14 & 2007 & $\begin{array}{l}\text { Strategic } \\
\text { assets } \\
\text { seeking }\end{array}$ & acquisition \\
\hline $\begin{array}{l}\text { Millenium Steel } \\
\text { Plc. }\end{array}$ & Thailand & 175.0 & & 2005 & $\begin{array}{l}\text { Market } \\
\text { seeking }\end{array}$ & acquisition \\
\hline NatSteel Asia Pte. & $\begin{array}{l}\text { Singapore with } \\
\text { operations in } 9 \text { East } \\
\text { Asia countries }\end{array}$ & 283.7 & 2 & 2004 & $\begin{array}{l}\text { Strategic } \\
\text { assets } \\
\text { seeking }\end{array}$ & acquisition \\
\hline $\begin{array}{c}\text { Joint venture with } \\
\text { Vietnam Steel } \\
\text { Corporation }\end{array}$ & Viet Nam & & 4.5 & 2007 & $\begin{array}{l}\text { Market } \\
\text { seeking }\end{array}$ & greenfield \\
\hline $\begin{array}{l}\text { Tata Steel KZN Pty } \\
\text { Ltd. }\end{array}$ & South Africa & $\begin{array}{l}\text { ZAR } 650 \\
\text { million }\end{array}$ & $\begin{array}{c}135,000 \\
\text { m.t. of } \\
\text { high } \\
\text { grade } \\
\text { ferro } \\
\text { chrome }\end{array}$ & $\begin{array}{l}\text { Under } \\
\text { construc } \\
\text { tion }\end{array}$ & $\begin{array}{l}\text { Market } \\
\text { seeking }\end{array}$ & greenfield \\
\hline $\begin{array}{l}\text { Carborough Downs } \\
\text { Coal Project }\end{array}$ & Australia & $5 \%$ stake & $\begin{array}{c}58 \\
\text { million } \\
\text { m.t. of } \\
\text { raw coal }\end{array}$ & & $\begin{array}{l}\text { Natural } \\
\text { resource } \\
\text { seeking }\end{array}$ & acquisition \\
\hline \multicolumn{7}{|c|}{ Essar Steel's Overseas Subsidiaries/ Affiliates } \\
\hline Algoma Steel & Canada & 1500 & $\begin{array}{l}2.4 \\
\text { million } \\
\text { m.t. }\end{array}$ & 2007 & $\begin{array}{l}\text { Strategic } \\
\text { assets } \\
\text { seeking }\end{array}$ & acquisition \\
\hline Minnesota Steel & USA & & $\begin{array}{c}1.4 \\
\text { billion } \\
\text { m.t. of } \\
\text { iron ore }\end{array}$ & 2007 & $\begin{array}{l}\text { Natural } \\
\text { resource } \\
\text { seeking }\end{array}$ & acquisition \\
\hline Essar Vietnam & Vietnam & & 2 & Under & Market & greenfield \\
\hline
\end{tabular}




\begin{tabular}{|c|c|c|c|c|l|l|}
\hline Steel Corporation & & & $\begin{array}{c}\text { million } \\
\text { m.t. }\end{array}$ & $\begin{array}{c}\text { construc } \\
\text { tion }\end{array}$ & seeking & \\
\hline $\begin{array}{c}\text { Essar Steel } \\
\text { Caribbean }\end{array}$ & $\begin{array}{c}\text { Trinidad and } \\
\text { Tobago }\end{array}$ & & $\begin{array}{c}2.5 \\
\text { million } \\
\text { m.t. }\end{array}$ & $\begin{array}{c}\text { Under } \\
\text { construc } \\
\text { tion }\end{array}$ & $\begin{array}{c}\text { Market } \\
\text { seeking }\end{array}$ & greenfield \\
\hline
\end{tabular}

Source: compiled from websites of companies and business news.

The Chinese enterprises have undertaken many overseas investments as listed and summarized in Table 9. Although more details of the magnitude of investments and capacity etc. are not available from the company websites, the motivations are clear from the activities listed. For both Sinosteel as well as Baosteel, the major motivations for outward investments have been development of natural resources and trading of their products. There are hardly any investments in the direction of horizontal expansion abroad or internationalization of their operations.

Table 9: Outward Investments made by Leading Chinese Steel Companies

\begin{tabular}{|c|c|c|}
\hline Name & Country & Activity/ motivation \\
\hline \multicolumn{3}{|c|}{ Sinosteel's Overseas Subsidiaries/ Affiliates } \\
\hline Sinosteel International Holding CO., Ltd. & Hong Kong & $\begin{array}{l}\text { To manage business and capital operation of overseas } \\
\text { organs of Sinosteel. }\end{array}$ \\
\hline Sinosteel Australia Pty Ltd & Australia & $\begin{array}{l}\text { Operation \& Management of the Channar mining Joint } \\
\text { Venture Project, discovering investment opportunities } \\
\text { for resource development in Australia and trading. }\end{array}$ \\
\hline Sinosteel Australia Mining Pty., Ltd. & Australia & $\begin{array}{l}\text { Participate in the exploration, investigation and } \\
\text { developing of other iron ore resources. }\end{array}$ \\
\hline Sinosteel Uranium SA Pty., Ltd. & Australia & $\begin{array}{l}\text { exploration and mining development of Uranium and } \\
\text { other minerals. }\end{array}$ \\
\hline Sinosteel South Africa Pty.,ltd. & South Africa & $\begin{array}{l}\text { Resources development, International cooperation, } \\
\text { Commodity trading }\end{array}$ \\
\hline ASA Metals Pty., Ltd. & South Africa & $\begin{array}{l}\text { Chrome ore \& Charge Ferrochrome Producing; } \\
\text { Chrome ore \& Charge Ferrochrome Trade; Chrome } \\
\text { resource development }\end{array}$ \\
\hline Tubatse Chrome Minerals Pty. Ltd. & South Africa & Chrome mining \\
\hline Sinosteel India Pvt Ltd. & India & $\begin{array}{l}\text { Metallurgical resource and project development, trade } \\
\text { and logistics, technology service and equipment supply }\end{array}$ \\
\hline Sinosteel Germany GmbH & Germany & $\begin{array}{l}\text { Trading of metallurgical raw materials and steel } \\
\text { products, metallurgical equipments, metallurgical \& } \\
\text { mining machineries, spare parts etc. and logistics. }\end{array}$ \\
\hline China Sinosteel (Singapore) Pte., Ltd. & Singapore & $\begin{array}{l}\text { complete plant and technology know-how Import / } \\
\text { Export. strategy on investment and / or finance the } \\
\text { joint-venture for the exploitation of natural resources } \\
\text { and specific project cooperation. trading or re-export } \\
\text { trading, and facilitate with warehouse and ocean } \\
\text { transportation services. }\end{array}$ \\
\hline Sinosteel Brasil Metallurgical Trading Ltd. & Brazil & Metallurgical trading \\
\hline Sinosteel Gabon Company Ltd. & Gabon & $\begin{array}{l}\text { prospecting, exploration, mining, process and export of } \\
\text { minerals, logistic and project management. }\end{array}$ \\
\hline PT. Sinosteel Indonesia & Indonesia & $\begin{array}{l}\text { developing processing \& trading of metallurgical } \\
\text { mineral resources; trading and logistics of main \& } \\
\text { auxiliary metallurgical raw materials, products, and } \\
\text { spare parts; supply of metallurgical equipment and } \\
\text { related engineering technical service. }\end{array}$ \\
\hline PT. Sinosteel Indonesia Mining & Indonesia & $\begin{array}{l}\text { Supporting services for general mining and large-scale } \\
\text { trading }\end{array}$ \\
\hline Sinosteel (Cambodia) Co., Ltd & Cambodia & \\
\hline $\begin{array}{l}\text { Sinosteel Corporation Vietnam Representative } \\
\text { Office }\end{array}$ & Vietnam & $\begin{array}{l}\text { Representing Sinosteel Corporation and its subsidiaries, } \\
\text { assist Vietnamese steel factories and other clients in } \\
\text { business, oversight of Laotian and Kampuchean } \\
\text { businesses }\end{array}$ \\
\hline
\end{tabular}




\begin{tabular}{|c|c|c|}
\hline Sinosteel Corporation Turkey Representative Office & Turkey & $\begin{array}{l}\text { Marketing, Project follow-up, After-sales Service, } \\
\text { Information Collection, Consultation, and Promotion. } \\
\text { Liaison, Co-ordination, Service for current existing } \\
\text { projects. }\end{array}$ \\
\hline \multicolumn{3}{|c|}{ Bao Steel's Overseas Subsidiaries/ Affiliates } \\
\hline Baosteel Trading Europe GmbH & Germany & $\begin{array}{l}\text { trade and investment in Europe, Africa and Middle- } \\
\text { East. }\end{array}$ \\
\hline Howa Trading Co., Ltd & Japan & $\begin{array}{l}\text { trade in steel product, equipment, spare parts and } \\
\text { materials }\end{array}$ \\
\hline Baosteel Singapore Pte Ltd & Singapore & $\begin{array}{l}\text { trading of steel products in Singapore, Malaysia, } \\
\text { Indonesia, Philippines, Thailand, Vietnam, other } \\
\text { ASEAN countries and Southern Asia including India, } \\
\text { Pakistan, and Bangladesh. }\end{array}$ \\
\hline Bao-Trans Enterprises Ltd. & HongKong & \\
\hline Bao-Island Enterprises Limited & HongKong & \\
\hline Baosteel America Inc & USA & $\begin{array}{l}\text { sole agency for steel import \& export business of } \\
\text { Baosteel Group in North, Middle and South America. }\end{array}$ \\
\hline Baosteel Do Brasil LTDA & Brazil & \\
\hline Baovale Mineracao S.A. & Brazil & mining \\
\hline
\end{tabular}

Source: compiled from websites of companies and business news.

The Chinese companies seem to have practiced a division of labour between them regarding the geographical coverage. Sinosteel's major focus has been on Australia and Africa, while Baosteel seems to be focusing on Brazil and other western countries. Sinosteel's multiple investment proposals in Australia have attracted concerns. Sinosteel won permission in April 2008 to acquire Midwest, an Australian iron-ore company, but later applications have been stalled. An estimated US\$ 40 billion of Chinese acquisition proposals are waiting for approval of Australia's Foreign Investment Review Board. ${ }^{2}$

To sum up the emerging patterns from the above discussion, Indian enterprises in steel industry are seeking to internationalize their operations through OFDI while Chinese enterprises are mainly undertaking OFDI to secure their supply of raw materials for expanding production of steel in China. Therefore, all the OFDI flows do not necessarily lead to internationalization of a firm's operations. Some are just seeking access to raw materials and supporting its trading activities.

\section{Concluding Remarks}

In the era of globalization, different types of networks are evolving among countries that go beyond mere exports and investments and FDI outflows from developing countries now account for a significant proportion of global outflows. It has been observed that the focus of developing countries like India has shifted towards attaining strategic positions in specific areas like drugs and pharmaceuticals, chemicals and petrochemicals, IT and software, broadcast and communications and recently, steel. The government has supported emerging MNEs by providing appropriate policy framework and infrastructure so that they can boost overseas expansion.

Outward FDI is increasingly being used as a strategy of non-price competition by emerging MNEs for supporting trade, augmenting asset bundles and escaping protectionist barriers to enter markets. Indications for this change in motivation come from the changing geographical distribution and sectoral composition over the years from developing countries to developed

\footnotetext{
${ }^{2}$ The Economist, 12 July 2008: 68-9.
} 
countries and from traditional sectors to sunrise sectors. With rapid technological advances, liberalization of markets and establishment of regional trading blocs, the outflows of Indian FDI have moved away from the traditional simple technology goods to goods and services requiring high technological and skill content.

China's outward FDI has grown enormously, from initial hesitation to government promotion. Given the rapid economic development being witnessed in China and the mounting foreign exchange reserves, it is likely that China will emerge as a large source of FDI in the years to come. In contrast to China's initial interest in outward FDI aimed at acquiring natural resources, the major Indian outflows of FDI for natural resources have occurred only in the recent past. The main reason for Chinese FDI outflow has been the acquisition of natural resources where as for Indian FDI outflows, the main driving force has been internationalization of operations or acquisition of global footprints. It is very well demonstrated by the emerging patterns of OFDI made by Indian and Chinese enterprises in steel industry.

Indian MNEs have been latecomers on the global scene and are now rapidly trying to acquire global footprints through Greenfield investments and acquisitions of foreign firms. It would have been difficult to imagine a developing country steel company taking over a sizable European rival a few years ago but now it is a reasonable expectation given the accumulated managerial expertise and other ownership advantages in companies from India, China, Russia, Brazil and other emerging economies. In the coming years, the trend of OFDI and internationalization of enterprises from emerging countries is likely to further deepen. The trend is welcome from the point of view of developing countries as it diversifies options for them of sources of FDI and also for more cost effective and affordable processes and technologies than those available from conventional sources. 


\section{References}

Amsden, A. (1989). Asia's Next Giant: South Korea and Industrialization, Oxford: Toronto. Blomstorm, A. and Sharma, D. D. (Eds) (2003). Learning in the Internationalization Process of Firms, Edward Elgar: Cheltenham.

Chandrasekhar, C. P. (2007). 'Tata's Gamble: Triumph or Nemesis', One World South Asia, March 15.

Cheng, S. and Stough, R. R. (2007). 'The Pattern and Magnitude of China's Outward FDI in Asia', Paper presented at the ICRIER Project on Intra-Asian FDI Flows in New Delhi, April 25-26.

D'Costa, A. P. (1999). The Global Restructuring of the Steel Industry: Innovations, Institutions and Industrial Change. New York: Routledge

Dunning, J. H. (1981). 'Explaining the International Direct Investment Position of Countries: Towards a Dynamic or Developmental Approach', Weltwirtschaftliches Archiv, 117 (1), 3064.

Dunning, J. H. (1986). 'The Investment Development Cycle Revisited', Weltwirtschaftliches Archiv, 122 (4), 667-675.

Dunning, J. H. (1998). 'Location and the Multinational Enterprise: A Neglected Factor?' Journal of International Business Studies, 29 (1), 45-66.

Dunning, J. H. (2004). 'An Evolving Paradigm of the Economic Determinants of International Business Activity', Advances in International Management, 15, 3-24.

Dunning, J. H. (2006). 'Towards a New Paradigm of Development: Implications for the Determinants of International Business Activity', Transnational Corporations, 15 (1).

Dunning, J. H., van Hoesel, R. and Narula, R. (1996). 'Explaining the 'New' Wave of FDI from Developing Countries: The Case of Taiwan and Korea', MERIT Research Memoranda No 009.

Dunning, J. H., van Hoesel, R. and Narula, R. (1998). 'Third World Multinational Revisited: New Developments and Theoretical Implications', J. H. Dunning (Ed.) Globalization, Trade and Foreign Direct Investment, Pergamon: Oxford and New York.

Government of India (2000). Guidelines for Indian Joint Ventures and Wholly Owned Subsidiaries Abroad, Indian Investment Centre: New Delhi.

Government of India (2001). IIC - Monthly Newsletter, Indian Investment Centre: New Delhi.

Hong, E. and Sun, L. (2006). 'Dynamics of Internationalization and Outward Investment: Chinese Corporations' Strategies', The China Quarterly, 187, 610-634.

$\mathrm{Hu}$, X., Ping, H., Xie, C. and Hu, X. (2008). 'Globalisation and China's Iron and Steel Industry: Modelling China's Demand for Steel Importation', Journal of Chinese Economic and Foreign Trade Studies, 1 (1), 62-74.

Johanson, J. and Vahlne, J-E (1977). 'The Internationalization Process of the Firm - A Model of Knowledge Development and Increasing Foreign Commitments', Journal of International Business Studies, 8 (1), 23-32.

Liu, X., Buck, T. and Chang, S. (2005). 'Chinese Economic Development, the Next Stage: Outward FDI?' International Business Review, 14, 97-115.

Kumar, K. (1982). 'Third World Multinationals: A Growing Force in International Relations', International Studies Quarterly, 26, 397-424.

Kumar, N. (1986). 'Foreign Direct Investments and Technology Transfers among Develping Countries', in V. R. Panchamukhi (Eds.) The Third World and the World Economic System, RIS, New Delhi: Radiant Publishers, 139-165.

Kumar, N. (1991). 'Mode of Rivalry and Comparative Behaviour of Multinational and Local Enterprises: The Case of Indian Manufacturing', Journal of Development Economics, 35, 381-392. 
Kumar, N. (1995). 'Changing Character of Foreign Direct Investment from Developing Countries: Case Studies from Asia', UNU/INTECH Discussion Paper Series no. 9516.

Kumar, N. (1998). 'Emerging Outward Foreign Direct Investments from Asian Developing Countries, Prospects and Implications', in N. Kumar, Globalization, Foreign Direct Investment and Technology Transfers, Impacts on and prospects for developing countries, Routledge: UNU/INTECH, 177-194.

Kumar, N. (2007). 'Emerging Multinationals: Trends, Patterns and Determinants of Outward Investment by Indian Enterprises', Transnational Corporations, 16(1):1-26.

Kumar, Nagesh (2008) 'Internationalization of Indian Enterprises: Patterns, Strategies, Ownership Advantages and Implications,' Asian Economic Policy Review, forthcoming.

Kumar, N. and Siddharthan, N. S. (1997). Technology, Market Structure and Internationalization, Issues and Policies for Developing Countries, Routledge: UNU/INTECH.

Macharzina, K., Osterle, M-J. and Brodel, D. (2003). 'Learning in Multinationals', in M Dierkes, A. B. Antal, J. Child and I. Nonaka (Eds.), Handbook of Organizational Learning and Knowledge, Oxford University Press: Oxford.

Marsh, P (2007). 'China keeps the Good Times Rolling', Financial Times Special Report, October 8.

Miller, R. M. (2006). 'Global Steel is Coming Together', Business Week, September 13.

Moon, H-C. and Roehl, T. W. 'Unconventional Foreign Direct Investment and Imbalance Theory', International Business Review, 10, 197-215.

Nolan, P. (2001). China and the Global Business Revolution. Palgrave: New York, 587-694. OECD (2007). International Investment Perspectives 2007: Freedom of Investment in a Changing World.

Sengupta, R. (2004). 'The Steel Industry' in S. Gokarn, A. Sen and R. R. Vaidya (Eds.) The Structure of the Indian Industry, Oxford University Press: New Delhi.

Tata Services (2006). Demand for Steel in India, Department of Economics and Statistics.

Vernon-Wortzel, H. and Wortzel, L. H. (1988). 'Globalization Strategies for Multinationals from Developing Countries', Columbia Journal of World Business, 23 (1), 27-35.

UNCTAD (2006). World Investment Report 2006, FDI from Developing and Transition Economies: Implications for Development, United Nations: New York and Geneva.

Wu, H. and Chen, C. (2001). 'An Assessment of Outward Foreign Direct Investment from China's Transnational Economy, Europe-Asia Studies, 53(8), 1235-1254.

Yang, D. (2005). China's Offshore Investments: A Network Approach, Edwar Elgar Publishing: Northamption, 133-160. 


\section{The UNU-MERIT WORKING Paper Series}

2008-01 Science, Technology and Development: Emerging concepts and visions by Luc Soete

2008-02 Reframing technical change: Livestock Fodder Scarcity Revisited as Innovation Capacity Scarcity. Part 1. A Review of Historical and Recent Experiences by Andy Hall, Rasheed Sulaiman V., Mona Dhamankar, Peter Bezkorowajnyj \& Leela Prasad

2008-03 Reframing technical change: Livestock Fodder Scarcity Revisited as Innovation Capacity Scarcity. Part 2. A Framework for Analysis by Andy Hall, Rasheed Sulaiman, V. and Peter Bezkorowajnyj

2008-04 Reframing technical change: Livestock Fodder Scarcity Revisited as Innovation Capacity Scarcity.Part 3. Tools for Diagnosis and Institutional Change in Innovation Systems by Andy Hall, Rasheed Sulaiman and Peter Bezkorowajnyj

2008-05 Is Inter-Firm Labor Mobility a Channel of Knowledge Spillovers? Evidence from a Linked Employer-Employee Panel by Mika Maliranta, Pierre Mohnen \& Petri Rouvinen

2008-06 Financial Constraints and Other Obstacles:Are they a Threat to Innovation Activity? By P. Mohnen, F.C. Palm, S. Schim van der Loeff and A. Tiwari

2008-07 Knowledge-based productivity in 'low-tech' industries: evidence from firms in developing countries by Micheline Goedhuys, Norbert Janz and Pierre Mohnen

2008-08 The Voyage of the Beagle in Innovation Systems Land.Explorations on Sectors, Innovation, Heterogeneity and Selection by Martin Srholec \& Bart Verspagen

2008-09 Crafting Firm Competencies to Improve Innovative Performance by Boris Lokshin, Anita van Gils \& Eva Bauer

2008-10 The Economics and Psychology of Personality Traits by Lex Borghans, Angela Lee Duckworth, James J. Heckman \& Bas ter Weel

2008-11 Embedding Research in Society: Development Assistance Options for Supporting Agricultural Innovation in a Global Knowledge Economy by Andy Hall

2008-12 Playing in Invisible Markets: Innovations in the Market for Toilets to Harness the Economic Power of the Poor by Shyama V. Ramani

2008-13 Explaining Success and Failure in Development by Adam Szirmai

2008-14 Running The Marathon by William Cowan, Robin Cowan and Patrick Llerena

2008-15 Productivity effects of innovation, stress and social relations by Rifka Weehuizen, Bulat Sanditov and Robin Cowan

2008-16 Entrepreneurship and Innovation Strategies in ICT SMEs in Enlarged Europe (EU25) by Kaushalesh Lal and Theo Dunnewijk

2008-17 Knowledge Transfers between Canadian Business Enterprises and Universities: Does Distance Matter? By Julio M. Rosa \& Pierre Mohnen

2008-18 Multinationals are Multicultural Units: Some Indications from a Cross-Cultural Study by Nantawan Noi Kwanjai \& J. Friso den Hertog 
2008-19 The Innovativeness of Foreign Firms in China by Branka Urem, Ludovico Alcorta and Tongliang An

2008-20 Beyond the emission market: Kyoto and the international expansion of waste management firms by Ionara Costa, Asel Doranova and Geert-Jan Eenhoorn

2008-21 The 'making of' national giants: technology and governments shaping the international expansion of oil companies from Brazil and China by Flavia Carvalho and Andrea Goldstein

2008-22 If the Alliance Fits . . . : Innovation and Network Dynamics by Robin Cowan \& Nicolas Jonard

2008-23 Facing the Trial of Internationalizing Clinical Trials to Developing Countries: With Some Evidence from Mexico by Fernando Santiago-Rodriguez

2008-24 Serving low-income markets: Rethinking Multinational Corporations' Strategies by Shuan SadreGhazi and Geert Duysters

2008-25 A percolation model of eco-innovation diffusion: the relationship between diffusion, learning economies and subsidies by Simona Cantono and Gerald Silverberg

2008-26 New Europe’s Promise for Life Sciences by Sergey Filippov and Kálmán Kalotay

2008-27 A closer look at the relationship between life expectancy and economic growth by Théophile T. Azomahou, Raouf Boucekkine, Bity Diene

2008-28 Regional Capital Inputs in Chinese Industry and Manufacturing, 1978-2003 by Lili Wang \& Adam Szirmai

2008-29 Worker remittances and government behaviour in the receiving countries by Thomas Ziesemer

2008-30 Strategic motivations for Sino-Western alliances: a comparative analysis of Chinese and Western alliance formation drivers by Tina Saebi \& Qinqin Dong

2008-31 Changing Configuration of Alternative Energy Systems by Radhika Bhuyan and Lynn Mytelka

2008-32 Promoting clean technologies: The energy market structure crucially matters by Théophile T. Azomahou, Raouf Boucekkine, Phu Nguyen-Van

2008-33 Local Knowledge Spillovers, Innovation and Economic Performance in Developing Countries: A discussion of alternative specifications by Effie Kesidou and Adam Szirmai

2008-34 Wage effects of $R \& D$ tax incentives: Evidence from the Netherlands by Boris Lokshin and Pierre Mohnen

2008-35 Cross-border Investment and Economic Integration: The Case of Guangdong Province and Hong Kong SAR by Naubahar Shari and Can Huang

2008-36 Radical versus non-radical inventions by Wilfred Schoenmakers, Geert Duysters \& Wim Vanhaverbeke 
2008-37 Localized Innovation, Localized Diffusion and the Environment: An Analysis of $\mathrm{CO}_{2}$ Emission Reductions by Passenger Cars, 2000-2007 by Bart Los and Bart Verspagen

2008-38 The economic impact of AIDS in sub-Saharan Africa by Théophile T. Azomahou, Raouf Boucekkine, Bity Diene

2008-39 Further results on bias in dynamic unbalanced panel data models with an application to firm $R \& D$ investment by Boris Lokshin

2008-40 A multilevel analysis of innovation in developing countries by Martin Srholec

2008-41 Experimentation with strategy and the evolution of dynamic capability in the Indian Pharmaceutical Sector by Suma Athreye, Dinar Kale \& Shyama V. Ramani

2008-42 The Impact of Social Capital on Crime: Evidence from the Netherlands by I.Semih Akcomak and Bas ter Weel

2008-43 Portrait of an Odd-Eyed Cat: Cultural Crossing as a Trademark for a Dutch-Thai Strategic Alliance by Nantawan Noi Kwanjai \& J Friso den Hertog

2008-44 The challenge of measuring innovation in emerging economies' firms: a proposal of a new set of indicators on innovation by Luciana Manhães Marins

2008-45 Intra-firm Technology Transfer and $R \& D$ in Foreign Affiliates: Substitutes or Complements? Evidence from Japanese Multinational Firms by Rene Belderbos, Banri Ito, Ryuhei Wakasugi

2008-46 To Be or Not to Be at the BOP: A One-North-Many-Souths Model with Subsistence and Luxury Goods by Adriaan van Zon and Tobias Schmidt

2008-47 Habit Formation, Information Exchange and the Social Geography of Demand by Zakaria Babutsidze and Robin Cowan

2008-48 Agenda Disputes and Strategic Venue Preferences: The Doha Crisis and Europe's Flight to Regionalism by Francisco P. Toro

2008-49 The determinants of the outward foreign direct investment of China and India: Whither the home country? by Paz Estrella Tolentino

2008-50 Comparing Chinese and the Indian Software MNCs: Domestic and Export Market Strategies and their Interplay by Jorge Niosi and F. Ted Tschang

2008-51 Internationalising to create Firm Specific Advantages: Leapfrogging strategies of U.S. Pharmaceutical firms in the 1930s and 1940s \& Indian Pharmaceutical firms in the 1990s and 2000s by Suma Athreye and Andrew Godley

2008-52 Internationalization and Technological Catching Up of Emerging Multinationals: A Case Study of China's Haier Group by Geert Duysters, Jojo Jacob and Charmianne Lemmens

2008-53 India's Outward Foreign Direct Investments in Steel Industry in a Chinese Comparative Perspective by Nagesh Kumar and Alka Chadha 
${ }^{\mathrm{i}}$ See Gopinath (2007). 